\title{
SOVIET RUSSIA
}

$\mathrm{O}^{\mathrm{N}}$ Sunday, June 22, the Nazi war machine was set in motion against Soviet Russia, without even the prelude of an ultimatum.

One by one the nations of Europe have been made subject to direct or indirect Nazi domination, and, with the failure of early attempts to break the resistance of the British Empire and the Free men of the occupied countries now fighting with us, and in apprehension of the effect of the growing weight of support from the United States, the Nazis have turned to the east in an attempt to seize the natural resources of Soviet Russia and to immobilize her armies. Beyond the immediate aims there is little doubt that the intention is to foment strife beyond Europe, in Iran, India and China, and elsewhere in Asia. It is all part of the gigantic scheme to dominate the world by terror and force, to subdue the peoples of all countries and to make them the slaves, body and soul, of Germany.

Mr. Winston Churchill drew a moving picture of the situation as he described it in a broadcast to the world on the evening following the invasion. "It is not too much to say, here this summer evening, that the lives and happiness of a thousand million additional human beings are now menaced with brutal Nazi violence. . . . The Nazi regime is indistinguishable from the worst features of Communism. It is devoid of all theme and principle except appetite and racial domination. It excels all forms of human wickedness in the efficiency of its cruelty and ferocious aggression." A vital decision had to be taken at once by His Majesty's Government, and there will be agreement everywhere with Mr. Churchill's announcement: "We have offered to the Government of Soviet Russia any technical or economic assistance which is in our power and which is likely to be of service to them." It matters not what political label be given for the time being to any nation or group of peoples; we cannot withhold our support from anyone who attempts to withstand the Nazi menace.

Soviet Russia has passed through many vicissitudes since it began to emerge from the Revolution of 1917. Internal difficulties have been numerous. There have been hardship and cruelty. But slowly, and with many hesitating moves, a system of government was built up which bound together the vast Russian territories in Europe and Asia into an organic whole. Some of us may not have sympathized with the ideological background which was developed; others have hailed the evolution of Soviet Russia as a symbol of the form of organized society towards which the nations should move. As Mr. Churchill said, all this must now be put aside. We are faced with an elemental fact. The Russian people now attacked are men and women. They have grown up with a measure of self-government. They have developed the industries of their country ; education has been promoted; science and scientific research have received support. Institutes devoted to research have begun to function, as many communications published in Nature from time to time until a few months ago have shown. Freedom of research as the English-speaking nations know it has not yet been achieved; nevertheless valuable work has been done. We need only recall in this connexion the names of the physicists Kapitza and Joffe, and of the geneticist Vavilov, all of whom have international reputations. These people are being attacked by the sworn enemy of democracy and all that it stands for: "Any man or State who fights Nazism will have our aid."

The attack on Soviet Russia represents, as Mr. Churchill put it, the fourth elimacteric in this War ; it was marked by "the same kind of outrage against every form of signed compact and international faith which we had witnessed in Norway, Denmark, Holland and Belgium". Freedom of thought leads to freedom of speech, one of the cardinal principles of democracy. This in turn requires the recognition by the individual of the rights and liberties of others; individual liberty must submit to restraints imposed by the needs of society. Such restraints may or may not be codified and become laws, but their observance is a condition upon which the continuance of human society depends. Similarly, in the field of international relationships, the rights of the several nations to their own modes of government must be respected, and the terms of solemnly pledged treaties must be honoured. It will be the task of men of all races, creeds and parties, so to work together after the War that lawbreaking among the nations becomes impossible. Lawlessness in international affairs is inimical to the progress of civilization. 